Teknokultura. Revista de Cultura Digital y Movimientos Sociales

ISSNe: $1549-2230$

http://dx.doi.org/10.5209/TEKN.68748

\title{
Music streaming and its consequences within the dynamics of power, consumption and creation
}

\author{
Ulises Hadjis Labarca ${ }^{1}$
}

Recibido: 10 de abril de 2020 / Aceptado: 9 de noviembre de 2020 Open peer reviews

\begin{abstract}
Streaming has dominated the consumption of music and audiovisual media over the last five years. $80 \%$ of music in Mexico is now consumed through streaming (Gutiérrez, 2019) and YouTube, Netflix and Spotify present an unquestionable hegemony in the Western world. This article shows how consumption through the streaming of music tracks, in conjunction with non-possession, opens up a new space in the world of music production and distribution, which in many aspects changes the creation of composers. The article also considers the power dynamics of the recommendation algorithm on various platforms.
\end{abstract}

Keywords: hegemony; recommendation algorithms; songwriting; Spotify.

\section{[es] Streaming de música y sus consecuencias en las dinámicas de poder, consumo y creación}

Resumen. En los últimos 5 años el streaming ha dominado el consumo de música y medios audiovisuales. Supone el 80\% de la música en México (Gutiérrez, 2019). Asimismo YouTube, Netflix y Spotify presentan una hegemonía incuestionable en el mundo occidental. El ángulo que me interesa mostrar aquí es cómo el consumo a través del streaming de tracks musicales inaugura un nuevo espacio en el mundo de la producción y distribución de música, que en muchos aspectos cambia la creación de compositores. También reparamos en la dinámica de poder que se encuentra bajo el algoritmo de recomendación en varias plataformas.

Palabras clave: algoritmos de recomendación; composición de canciones; hegemonía; Spotify

Summary. 1. Introduction. 2. Origins of streaming 3. Spotify 4. The recommendation algorithm. 5. The algorithmic subject. 6. Playlistism. 7. Platform capitalism. 8. The algorithmic songwriter. 9. Conclusions. 10. References.

Cómo citar: Hadjis Labarca, U. (2021). Music streaming and its consequences within the dynamics of power, consumption and creation. Teknokultura. Revista de Cultura Digital y Movimientos Sociales, 18(1), 3-12.

\section{Introduction}

Currently, streaming has taken a good amount of the share of mass media consumption: movies, TV series, music, classes from experts, and even books. Although it represents an improvement from physical media in many aspects (its access is easier, it's more ecological and it's cheaper to produce), it also has many issues that are not talked about on a regular basis. The political aspect of this "utopian" mass consumption, is not often discussed in the context of digital capitalism, or in the words of Srnicek (2017), where data is the main resource to work with. Many issues appear when we take a closer look: how the owner of a platform can make any content vanish at any time without leaving any trace; the way the algorithms are a facade for corporate interests, and also how the platform can shape the creative output of musicians.

\section{Origins of streaming}

Perhaps the dynamics of streaming were preconfigured in what Flichy $(2011$, p. 11) calls a phantasmagoric utopia: "phantasmagoric utopia is an escape, a way out, a refusal to face the technical reality". Given the deep relationship that recording and musical distribution had with the material world (tapes, slow and expensive equipment, fragile and perishable vinyl records), maybe the digital recording and distribution were preconfigured

\footnotetext{
Universidad Iberoamericana de la Ciudad de México (México)

E-mail: uliseshadjis@gmail.com
} 
in the industry; the desire to be able to create and distribute music without such a tiresome technical mediation. As Benjamin (2008, p. 21) says, every era dreams of the following one: "Just as the illustrated newspaper virtually lay hidden within lithography, so the sound film was latent in photography".

Also, maybe in a naive way, the rise of digital music was tainted with the "free access ideology" of the beginnings of the internet: "for nearly twenty years the Internet developed outside the market economy. Free-of-charge products and cooperation were at the heart of the Internaut culture and market exchange was even proscribed" (Flichy, 2011, p. 179). In the same way a horizontal collaborative peer model was set out as an example in the Linux operating system, where ten thousand volunteers worked in its realization. This ideology is very well posed in this excerpts that Galloway takes out of Levy's ideas:

Access to computers... should be unlimited and total. All information should be free. Mistrust authoritypromote decentralization. Hackers should be judged by their hacking, not bogus criteria such as degrees, age, race, or position. You can create art and beauty on a computer. Computers can change your life for the better (Galloway, 2004, p. 152).

Maybe this is why streaming is still today sold with a "utopian vibe" of freedom and equality, and with no intermediaries between the creators and the consumers: our mission is to unlock the potential of human creativity-by giving a million creative artists the opportunity to live off their art and billions of fans the opportunity to enjoy and be inspired by it (Spotify, 2020).

After reviewing several sources, I found Hesmodhalgh's (2019) definition of streaming to be one of the most exact: "the term 'streaming' refers to how music is no longer owned by consumers, as in previous models: instead, the music 'flows' temporarily to users. Access is paid for either by monthly subscription, or made available 'free' on an advertising-supported basis". The content then flows through the audience, it is dynamic by nature and therefore ephemeral. It is now a fact that the consumption of media is no longer linked to the notion of ownership; this I think is one of the most interesting features of the phenomenon of streaming.

\section{Spotify}

Although there are many streaming services, in this paper we will focus on Spotify, because of its enormous share of the music streaming market, its similarity with social media's dynamics (followers, likes, play numbers) and that it is a stand alone streaming company, unlike Apple or Amazon.

Spotify was born from an illegal system of sharing peer to peer, they began sharing music that they did not have a license to private users. However, that step from illegality to legality, as Marshall (2015) insists, has been a constant in the music industry: first a practice appears that damages the possibilities of profit of those who own or control the copyright, the owners then try to repress the practice without success, and later appropriate it in a way in which they manage to make money out of it.

Advertising was supposed to make up for the "free" availability of music on Spotify, but it was not the case:

In 2015, Spotify's declared 'best year ever', ad revenue accounted for only 10.1 percent of total income, with the remaining 89.9 percent coming from people paying for premium accounts... Spotify still lost money for more than a decade (Eriksson, Fleischer, Johansson, Snickars, Vonderau, 2019, p. 155).

Which leads to the reasonable suspicion that the company uses music to profile its users and sell them as data to third parties:

Playlists tailored to specific urban activities (such as "Morning Commute") and moods (such as "Life sucks") are combined with data on genre preferences, age, gender, geography, language, and streaming habits, alongside information from third-party data providers about broader interests and lifestyle and shopping behaviors. It is, in short, a business model based on technologically aided information exchanges -not music (Eriksson et al., 2019, p.67).

This supposed horizontality and free access were the premises of Spotify and YouTube in the beginning: you upload your content yourself and the public will be able to access it for free. Given the failure of advertising dynamics (at least in the case of Spotify), both have opted for a premium (advertising-free) subscription model, that replicates the old newspaper/magazine/cable TV dynamic: you pay for a service that conglomerates ad-free content.

\section{The recommendation algorithm}

In the era of radio and physical media, users couldn't immediately access songs as they wished: they had to wait for the song to be played on the radio or until they could afford to go and buy the record, but even rich people couldn't have all the music in the world. Now with streaming, people can access to most of the recorded music available. Drott (2018), inspired by Lacan, notes the problem of this dynamic where the viewer has full control, coupled with the oversupply of content to choose from:

If desire is a function of lack, then the unlimited and inexhaustible musical plenitude to which streaming services provide access does not fulfill desire so much as short-circuit it. By removing barriers to the immediate satisfaction of musical desire, streaming platforms inadvertently transmute a potential source of gratification into its antithesis. In a way, streaming servicesriskendingupas victims of theirownrhetorical success, as their promise of saturating musical desire has the unintended effect of suffocating it instead (Drott, 2018, pp. 332-333).

In the same way that rich people find it difficult to articulate their desire due to the lack of fault, the same can happen to the Spotify user: to be paralyzed by so 
many "equally good" options as Buridan's ass. Given this problem, all platforms have managed to skew the content offered from the curatorship; that is to say, not all users are shown all the options, but a reduced amount that, based on different criteria, is thought to be more attractive and appropriate and will maintain their interest in the platform. Although services like Tidal are committed to a curatorship made by celebrities and experts, and although these agents collaborate in the curatorship of many playlists, broadly the curatorship comes from the algorithm.

Logician and computer scientist Kowalski, thinks that "an algorithm can be regarded as consisting of the logic component, which specifies the knowledge to be used in solving problems, and a control component, which determines the problem-solving strategies by means of which that knowledge is used" (Kowalski, 1979, p. 424). We can also see it (broadly), as a mathematical function similar to a flowchart where each possibility of action triggers an appropriate response to it: if $\mathrm{A}$ happens do $\mathrm{B}$; If $\mathrm{C}$ happens do D. In the case of music streaming, a piece of software makes profiles of each song or movie and then the algorithm, based on that information, recommends the user things that come close to that profile; but there are a lot of implications regarding this dynamic.

First, how does the software make such song profiles? Platforms like Pandora pay experts to analyze each song in pointers that they call genes; distinctive features of each track with which the algorithm can interact. Here Platoni (2006) exemplifies the dynamics from a song by rap artist Eminem:

"Lose Yourself" thus has a gene describing whether the bass is played ostinato or as a riff, and another for whether the kick drum sound is tight or booming. There are genes for handclaps, turntable scratches, and organ solos - times 235. In fact, the four genres, or "genomes," these music analysts have scrutinized to date - jazz, hip-hop/electronic, rock/pop/country, and world music - contain a total of about four hundred genes. Some are genre-specific - hip-hop, for example, has no need of the jazz gene that counts improvised sax licks (Platoni, 2006, p. 1).

Robert Prey explains how many genes are involved:

Rock and pop songs have 150 genes, rap songs have 350 , jazz songs have approximately 400, while world and classical music have between 300 and 500 genes .For example, since rap music is lyrically driven, it requires a greater list of subsets of genes within the category of lyrics (rhyme schemes, degree of profanity, etc.) (Prey, 2018, p. 1089).

What this new way of labeling content is looking for, is to go through closed styles such as pop, jazz and electronics and generate new association chains so the algorithm can present the listener with new music that is unrelated to the identity associated with a specific genre: for example if you really like John Mayer's live albums, a Pat Metheny suggestion may pop up because of the "guitar solo" gene.

But there is not always a human being involved in the categorization of music. Spotify, BBC, Twitter and other platforms delegate the task of analyzing each song to the Echo Nest company:

The Echo Nest generates the bulk of its data through a technique called machine listening...The Echo Nest relies largely on computer extraction of data. Their software parses an entire song in a few seconds and processes the signal into thousands of unique segments, including timbre, beat, frequency, amplitude, vocal syllables, notes and other computermeasurable characteristics (Morris, 2015, p. 453).

In other words, the success or failure of a song on Spotify depends on how the data it contains can be processed by the software into relevance. This is important, to the extent that as this algorithmic capitalism dynamic continues to gain space, the creators of content, singer-songwriters or bands, will begin to create work (consciously or unconsciously) that best suits gene recognition software or accentuate in their work those genes to excel in face of the oversupply. For example, if timbre is a relevant value for the software but not rhymed syllables, musicians probably worry less about rhyming and more about getting better sounds from their synthesizers.

On the other hand, the algorithm also has some complicated aspects from the consumer's side. First, the so-called profiling, that is, the way in which the algorithm outlines, or boxes each user within a demographic profile, what John Cheney-Lippold calls the new algorithmic identity:

You open up a new computer and fire up a web browser. You go to the washingtonpost.com, visit a couple of blogs at Wordpress and Tumblr, and go on the business social networking site linkedin.com. Maybe you take a break from the internet, go grab a cup of coffee, but return to watch some videos on Hulu, check US gossip at tmz.com, and look at the weather at wunderground.com At this point you decide it might be best to go to work so you close your computer, get dressed, and go outside. While you may proceed with your day as if nothing has happened, something has changed about who you are online. You have been identified. Your IP address has been logged; you have a cookie file installed on your computer. And somewhere, in a database far, far away, you very well may have a gender, class, and race (Cheney-Lippold, 2011, p. 165).

This new algorithmic identity is a trail that mediates all our consumption on the internet (which at this time can be considered the majority of our consumption), based on the profile we are creating on Facebook, Twitter, Netflix, Amazon, Spotify, based on likes, retweets, on the things we ignore and the ones we pay attention to, movies stopped in the middle or songs we play many times; we are following the recommendations that the algorithm will make for us. The algorithm is presented 
as an oracle of cybermodernity, as a Computational Objectivity (Morris, 2015), to the extent that its recommendations are not the product of a whim or a hunch, but of a scientific process, which is therefore infallible: in the same way that a doctor recommends certain vitamins after an exhaustive hematological analysis, the algorithm recommends certain films and records after a thorough computerized analysis. This is a scientific overestimation that benefits the interests of other individuals: as long as my interests as a corporation hide behind "Dr. Algorithm PhD", it will be easier to generate control over the collective.

This curation/distribution process is what Bruno Latour calls mediation: "Mediators transform, translate, distort, and modify the meaning or the elements they are supposed to carry" (Latour, 2005, p. 39). Or they are similar to what Bourdieu called a Cultural Intermediary: a sort of petit bourgeois who, through TV and other mass media, called out some things better than others and distinguishes between cultural content. Jeremy Morris defines them: "Intermediaries, then, are contextually specific actors who are involved in framing the interactions between cultural goods and those who encounter them, and they do so by virtue of the cultural legitimacy they accrue" (Morris, 2015, p. 449). This agent must add a new framework or meaning to the content it carries. This work, before the streaming, fell to the hands of the employee of the video rental store, the bookseller or the clerk of the record store. In fact, the filmmaker Cameron Crowe reports that, that was the very reason that made him buy the Beach Boys" "Pet Sounds" LP: "I was thirteen, and I wanted to buy a Jackson 5 cassette. The knowing geek behind the counter shook his head and advised me to get Pet Sounds instead. Desperate for his cool-guy validation, I bought it" (Crowe, 2003, p. 1). Right now the mediator is no longer a human being but the algorithm: "If we previously looked to cultural intermediaries like the bookstore retailer, the film festival programmer or the radio DJ to help curate culture, algorithms and recommendations services increasingly carry out these roles" (Morris, 2015, p. 448).

Tia DeNora notes how homogeneous music consumption can be nowadays, even in public spaces:

During an ethnography of high street retail shops I was intrigued to learn that the larger of the national and global outlets not only play the same music at precisely the same times of day, but they do so in order to structure the energy levels of staff and clientele. In principle, one should be able to enter any one of these stores at any moment in any branch in the United Kingdom and the music playing should be (or at least is intended to be) identical. At a time when public spaces are increasingly being privatized, and when 'people management' principles from McDonald's and Disneyland are increasingly applied to shopping precincts, sociologists need to focus much more closely on music's social role (DeNora, 2004, p. 19).

No longer can a store clerk put on some music to make the work space more personal; headphones are the place to put your own music. The public space must remain corporate.

Frith (1986) saw record consumption as an active process for the music lover: he goes to a store, has a dialogue with the shelves, with the store's employee, with the prices of the records. That form of consumption gave much more space to contingency: an LP could be on sale and you may buy it without knowing much of it, or the single that you intended to buy in first place could be sold out and that would displace the attention to other titles. Right now, for a fixed price we have unlimited access to an extensive amount of knowledge; the available offer far exceeds our consumption capacity, so as in social networks, the algorithm appears to mediate our relationship with music. Before, the limited amount of money we had and the records that were available at the store did it: now it is an algorithm, which is a kind of collection that each user must take care of, a public image, to the point that Spotify offers the option of being able to listen to tracks in a hidden way, to have guilty pleasures without anyone noticing, an impossible thing in the age of the physical disc, as this song by singer-song writer Domingo en Llamas illustrates:

Is it true that you will visit me?

Don't surprise me, tell me ahead of time please.

I will take advantage and clean the shelves

but the important thing is where will I hide

the records I never wanted you to see.

We can no longer enter someone's house for the first time and snoop around their records to see who he is and who he has been. Nor do we have to force ourselves to listen to a record six times because we already bought it, or just take a record to your house because it was very cheap; nobody will give us a record that he doesn't like anymore. Streaming has over-subjectivized music consumption. Music is no longer something you put in your living room and share with your family in speakers; but something you do on your cell phone with headphones on: listening to music is increasingly moving away from its probable ritual/tribal origin, and is now something you have to keep to yourself, to hear with headphones; like masturbation, music listening is becoming a private practice.

\section{The algorithmic subject}

Logically, mediation usually responds to economic and ideological interests, and this new algorithmic version is no exception. The music industry is largely focused on the young population, which differs from people in their 30 s and above, who have a "frozen taste" (Eriksson, et al., 2019); teenagers are more susceptible to receiving new music. In a study conducted by these authors, they noticed how the Spotify algorithm recommended older users more particular music than it did to younger users with the same listening habits.

The pairs with the oldest bots seemed to be provided with a much more diverse set of artists than the 
younger age pairs... On the one hand, the results could be taken as a suggestion that our older bots, supposedly suffer a form of taste freeze, and needed special (that is, more) help to find music, and thus received a greater number of recommended artists (Eriksson et al., 2019, p. 33).

It should be mentioned that their older bots were 60 and 90 years old, but it definitely shows how age is a determining factor in this algorithmic dynamic, while gender, according to the study of the authors, is not (bots of different genders who listened to the same music were recommended the same). Be that as it may, the subjectivization of musical consumption is not as simple as that: "A preliminary conclusion to draw from the experiments with Spotify Radio is that similar artists reappeared frequently within all bot playlists... Giving Spotify Radio the user feedback of "thumbs up" (like), "thumbs down" (dislike), or skip did not produce significant differences in the results" (Eriksson et al., 2019, p. 101).

Although the Spotify differentiator has been from the beginning its advanced algorithm and how this helps you discover new music, it seems that beyond your interaction with the algorithm, some recommendations are already predetermined for everyone. Logically, the algorithm is not an autonomous entity devoid of an ideological burden, and promotes some kinds of music, identities, activities, and countries over others. Morris agrees:

(...) recommendation systems are not entirely autonomous systems. They depend highly on the people who design them and use them. Rather than neutral or objective technologies of presentation, algorithms and recommendation services are the result of the interactions of human actors (within a market context) and code (acting in both intended and unintended ways) seeking to frame meaning and curate experiences using a given set of raw materials (a database) and towards a distinct end (increasing listening time, pointing users to other related commodities, etc.) (Morris, 2015, p. 452).

But the algorithm continues to be portrayed as an autonomous and pure agent whose only interest is to help the user in a selfless way, a kind of Trojan Horse of corporations.

Something relevant in this whole panorama is the phenomenon called profiling, which we have already hinted at previously: the algorithm creates user profiles based on their consumption patterns:

In order to recommend music that matches a listener's context, streaming platforms need to collect and aggregate data points on everything from a listener's location, to the content they are consuming, to their current emotional state. This is made possible by the proliferation of mobile devices such as the smartphone, which permits the collection of data points like location, motion, time of day, and nearby contacts. Increasingly, wearable 'smart' devices will provide continuous contextual signals that recommendation systems can draw on (Prey, 2018, p. 1092).

But it is even more interesting how this profiling tends to affect the subject's own conception: "The results of algorithmic governing are likely to affect how individual users conceive themselves" (Eriksson et al., 2019, p. 135). That is, if I am someone who listens to salsa, metal and electronics, but little by little the algorithm presents me with less and less metal music; maybe in a couple of years I will no longer consider myself a fan of metal, or think that quality metal is no longer made. However, most worrisome is how the emotions evoked by the metal will begin to disappear from my context and therefore cease to be validated by the art I consume.

Prey and Drott use the concept of dividuation to account for the phenomenon; Broadly speaking, the dividuation speaks of a much more dynamic and less definitive process with which the subject is divided from the collective, where a single subject can have a series of dividuals: "With the growing importance of contextaware personalization, it would appear that individuals are seen as multiplicities, or in Deleuzian terms, endlessly subdivided "dividuals"” (Prey, 2018, p. 1092). Or we can see it as "individual discomposed into a succession of dividuals" (Drott, 2018, p. 350). Drott thinks that although this process is dynamic and presents a degree of emancipation for consumption (if I start listening to Christian rock after years of listening to electronic music, the algorithm will eventually understand this new identity), it is not devoid of a control agenda:

Deleuze's, one inextricably tied to that of dividuation: what he referred to as 'control', a technique of power that does not operate according to a logic of compulsion or coercion, but according to a logic of adaptation. As Deleuze describes it, control adjusts to the in/dividual in the manner of 'a self-deforming cast that will continuously change from one moment to the other, or like a sieve whose mesh will transmute from point to point' (Drott, 2018, p. 336).

Then the control generated by the algorithm on the subject is not violent in a classical way, but rather, without realizing it, the subject adapts to a dynamic that is gradually imposed on him. In the first instance we could see that degree of control in profiling dynamics and its economic consequences. Virtually all of these platforms sell consumer data to third parties for targeted advertising; based on that, it is likely that the algorithm will offer the user songs or movies that accentuate their demographic profile and make it as one-dimensional as possible: to the Miami Latin American "reggaeton" to make them more Latino, for the upper class in New York: Glenn Gould. Eventually, that consumption will be modeling each subject towards a clearer demographic profile and therefore more attractive to sell to multinationals: very Latin Latinos, very millennial millennials, very conservative elders. This notion of taste as a static concept is a concern of Antoine Hennion: "Fans don't 
fight determinism. Among all the possible determinisms, they choose one. In this example the history of taste as a definition of oneself, considered by others as a type of repetition that is too stereotyped" (Hennion, 2010, p. 28). Taste should be a more dynamic concept.

In a Spotify ad, a user says. "I just want to meet a girl who loves me as much as my Spotify weekly discover list" (Eriksson et al., 2019, p. 84). The interesting thing is how users already have an awareness of their algorithmic alterations; therefore Spotify and Chrome have a hidden mode of navigation/consumption so that some "guilty pleasures" do not add to your algorithmic identity. This refers to a division of the subject in a conscious way: my offline self, and my online self, being the last one being more careful because each action leaves an indelible trail, while in the offline world only a small part of my actions are recorded permanently.

\section{Playlistism}

The playlist is a direct heir of the cassette mixtape: a way to disarm the album format (where a group of songs came pre-established in terms of order and artists) and customize it, mainly to evoke a new emotional discourse. Within streaming platforms, playlists have become the main vehicle for song consumption. The playlist has already taken the bulk of streaming music consumption:

In early June, Mulligan surveyed 1,500 U.S., UK, and French respondents. Overall, 29\% said they mainly listen to albums, while $31 \%$ said they mainly listen to playlists. Among the generally younger and more pop-oriented participants who listen to free streaming music, $45 \%$ said they mainly listen to playlists, and 31\% said they mainly listen to albums. As for paid subscribers, $60 \%$ said they mainly listen to albums, while $68 \%$ said they mainly listen to playlists (participants could choose more than one answer) (Hogan, 2015, p. 5).

For the artist this presents at the same time an opportunity and a problem:

Thenagain, ifplaylistificationmeans fewertraditional superstars, advocates have an inkling it could also help shed light on artists who weren't previously famous. Two of the biggest success stories from Spotify's playlists so far are Lorde, who famously appeared on Napster co-founder Sean Parker's Hipster International playlist before she became an international sensation, and Hozier, who garnered $46 \%$ of his first plays on Spotify from the service's curated playlists last year (Hogan, 2015, p. 13).

Here I see excessive optimism. We are led to believe that there is now a horizontal process of massification: before an artist had to go through a sort of funnel held by record company bureaucrats to achieve massification, but now thanks to "Saint Algorithm" that is no longer necessary. If your song is a hit, the magic of the algorithm will take it to the top, an essentialist view of music. Logically that does not work in such a way; the interests of the big labels and the market continue to mediate the artist-public relationship, but perhaps now with greater opacity, like the Wizard of $\mathrm{Oz}$, hidden behind a magical veil.

Although mixtapes have historically covered a wide range of emotions and moments, the Spotify editorial playlists do not seem to be as broad; they confine themselves in broad strokes to the moments and emotions that a good citizen should have, accompanied by a good capitalist life:

(...) notion of temporality presented here is also bound up with chrono-normative prescriptions of "the good life" that instructs users to get out of bed, go to work (in a office), work out in the afternoon, and then socialize with friends, family, and lovers in the evening. Meanwhile, music is presented as a way of increasing productivity and performance in these time-bound activities... ten playlist categories are specifically related to activities and mind-sets: Mood, Party, Chill, Workout, Focus, Dinner, Sleep, Travel, Romance, and Kids and Family (Eriksson et al., 2019, p.121).

In addition, Prey marks the six contexts that Spotify chose to launch its sponsored playlist initiative: 'chill time', 'workout', 'party', 'dinner', 'focus', and 'sleep' (Prey, 2018, p. 1094). Another series of contexts of the good citizen accompanied by capitalism, chronormativity at its best. To reaffirm the authors, let's do a brief field investigation. Let's review some of the descriptions related to the first 16 lists that Spotify suggests to me on May 4, 2019:

Tropical Vibra: Give your day a good warm and fruity wave.

Sing in the shower: your personal karaoke to give it your all!

Joyful Hits: Your dose of energy to come up!

Happy Hits!: Hits to boost your mood and fill you with happiness!

The most beautiful songs in the world: Find beauty in a handful of songs.

Acoustic noon: Acoustic pop for your day.

Wake up and smile: Brighten your day with the most pop for the morning.

Young, Wild \& Free: That's how it's supposed to be. Living young wild and free.

FrienDeSemana: The most chill for your weekend.

Confidence Boost: You're on the top of the world. Don't forget it.

Happy Beats: Feel-good dance music.

Mood Booster: Get happy with this pick-me-up playlist full of current feel-good songs

Pura vida: Music for feeling good!

On the Road: A good animated mix to accompany you on your journey.

Indie melancholy: A musical selection for faint and taciturn feelings

Alone again: When everything is lonely, I can be with my best friend. 
Of the 16 lists, only the last two refer to emotions that are not happiness and a neutral one (acoustic noon). In other words, $81 \%$ of the music suggested by the algorithm is directly related to happiness and the good capitalist life. The worrying thing about this monochromatic happiness is how the multiplicity of music is being mutilated. If this continues to happen, within a few years artists will intuitively censor their work to adapt it to this dictatorship of happiness.

The images that accompany the playlists are of young people smiling, by day; they are loaded with what Lev Manovich (2016) calls Instagrammism²: the key aspect of Instagramism is the focus on mood and atmosphere rather than representation or communication of emotions (Manovich, 2016). The author is a great enthusiast of Instagramism; he considers it a new aesthetic discourse built collectively and not by an elite unlike other movements. I allow myself to rethink the term. I will extend Instagramism to a certain worldview that decants not only aesthetic but ideological premises that come from the social network: square photos, phrases that accompany the image, likes, views, followers and the dynamics of algorithmic accommodation that come from that. I feel that we can already find traces of the Instagrammism of the world: how people dress, how they eat food that looks well photographed or even how they plan activities that will be well portrayed in a photo or recording with the cell phone. Instagrammism already seems to mediate reality for many of us.

Another thing that this playlistism promotes is the notion that music is something to listen to tangentially and not with complete attention, something light that cannot be very demanding, so music becomes synonymous with superfluous, which authors like Allen Anderson (2015) call Neo-Muzak. As Daniel Ek has said: "soundtrack your entire day, then your entire life" (Eriksson et al., 2019, p. 149), not a second in silence.

The ontological conception of the subject for the algorithm is a static one: from a like or dislike we can eventually get to know the true subject, as one who manages to know a cave or a mineral, and does not consider the dynamic aspect of the subject: the song that the subject disliked or skipped a month ago, can represent him or her perfectly today. Prey doesn't share my algorithmic pessimism:

Spotify and Pandora do not conceive of individual music listeners as immutable subjects to be modeled. There is no territory to be mapped. There is no 'real' to be represented. I am an urban travel enthusiast with a penchant for the Delta blues... until I am not. You are a suburban lover of smooth jazz... until you are not. In short, streaming platforms promise the potential of processual identity: of the perpetually 'becoming-individual' (Prey, 2018, p. 1095).

Another interesting phenomenon of playlistism is an unavoidable passivity towards the consumption

This neologism refers to the Instagram social network founded in 2010 to share photos which has had a giant growth in recent years reaching one billion users this year making it the most-used social network in the world. of music, which Drott (2018) calls "zero-button user interface", where you press it and the software is placing the music that "you want to hear" without the need for an anachronistic action like go to a store, see physical records, think about which one to listen to, see which one is cheaper, which one is on offer, ask a friend, etc.

\section{Platform capitalism}

Many of these platform capitalism companies (Drott, 2018) begin their operations calling themselves "technology companies", although in the background they are media companies: asked if Spotify would not qualify as a regular media company -given its declared business interest of providing content to audiences while selling those audiences to advertisers- Bendz rushed to praise Spotify's achievements as a tech company (Eriksson et al.,2019). Why does Spotify insist on not seeing itself as a media company? For Napoli and Caplan (2017), their first argument is that they do not produce content; although the authors insist that their role as mediators already makes them a media company, my hypothesis about their insistence on not being a media company is that they still do not make content and should keep those intentions secret. Think about Netflix. When the company started, it showed no interest in creating its own content, presenting itself simply as a technology company made companies like Disney or Fox put their content there without any problem. Once hegemony and almost a monopoly were achieved thanks to the content from third parties, Netflix began to generate its own content, which right now takes the center stage among their offerings. Although Spotify or Uber still don't make their own cars or music tracks, nothing makes us think they won't do it in the future. These companies insist on not presenting themselves as media companies, to not scare companies that now give them content to build a hegemony. The bigger the share of the company in the markets gets, the harder it is for the producer and the consumer to escape it:

As more passengers turn to Uber's platform, nonUber cab drivers will lose out and be forced onto Uber's platform if they are to survive. The same holds for passengers: as fewer non-Uber cabs roam the streets, the only way to guarantee a cab will eventually be through Uber's platform (Srnicek, 2017, p. 71).

In 2012, Forbes magazine called Spotify CEO Daniel Ek, "the most powerful person in the music business". This statement shows the media discourse on streaming that has been established, however, it is naive: the big three $^{3}$ control the industry, including Spotify. If the three big transnationals decided to remove their catalog from the platform, it would no longer have attractive content for the general public.

The main agenda of these streaming platforms is that the consumption of the public goes from a storage culture to a streaming culture, generating a situation where having files on your device is anachronistic and

That is the term that is used to refer to Sony, Warner and Universal. 
uncomfortable. It is no less the fact that the new solid state hard drives have radically reduced their storage capacity, a way perhaps to push users to keep their files in the cloud or simply consume them in streaming because the file sizes have become increasingly large for the sake of an endless fight for fidelity and a 'better quality'.

Although I pay for the Spotify premium service, I never own any track. At any time the platform can take it out of its services and I will never listen to it again, something that did not happen with physical media or even with digital downloads. Once the Mp3 was on my hard drive it was no longer dependent on the service provider to be able to be reproduced:

An analysis of art in the age of mechanical reproduction must do justice to these relationships, for they lead us to an all-important insight: for the first time in world history, mechanical reproduction emancipates the work of art from its parasitical dependence on ritual (Benjamin, 2005, p. 10).

Its emancipation from the ritual is undoubtedly an emancipation of the individual in regards to the collective: before lithographic prints I couldn't see notorious art in my own privates spaces; I had to go see an oil paintings and the like in a social space (museum, gallery, etc.). Now, thanks to streaming and headphones, music listening has lost a good part of its social character, and is on its way to become a solitary activity, but it has lost its complete detachment from the hegemonic figure, as in the physical format era.

In the past, the individual consumption of musical content was related to the notion of ownership: you bought a record and the record was yours, similar to a book or a picture. Logically, you did not buy the work in its ontological whole, that is to say the work did not belong to you (neither in its patrimonial nor in its moral right), but you owned a copy of said creation. Once a CD was purchased, the company had no way of removing it from our consumer space: they could suggest changing it for another, but they could never force us to comply. Even in the case of a defective disc, the customer always had the option of keeping it if they wanted to. Streaming has changed all that.

Spotify or Apple Music users do not own any content even though they have access to a large amount for their consumption. At the beginning of the era of digital consumption, the path seemed to be MP3 file downloads; however, this dynamic of consumption presented a problem inherited from offline consumption in physical formats: storage space. The more books or discs we have, we must find more space to store them. The same thing happened with the mp3: music lovers must have many hard drives to be able to store their MP3 collection. Streaming seemed to be the solution to that problem-millions of songs at your disposal without the problem of worrying about their storage, a utopia, or so it has been presented. But let's review the political dimension of this.

CDs and vinyl records are static information archiving objects: the content they archive can no longer be modified once their manufacture is complete. Streaming files can, and in fact, very often are: if an artist releases a song and days later they feel the voice needs more volume, they can remix it and replace the file for the track without anyone noticing. In fact, the consumer does not have to know. This means that the work is no longer a static entity but constantly dynamic. Although physical records have been remastered, remixed, and even rewritten throughout decades past, in each case the previous version was still archived somewhere. With the imminent closure of the iTunes Music Store (Reskinoff, 2018) there will be no way that previous versions of tracks will be archived in the public space. This dependence on streaming has an even more dangerous dimension: the absolute disappearance of the content from the market.

The contracts of the big labels have a discontinuation clause; the label reserves the right to erase the recording of any artist from public light if they deem it appropriate. Some years ago that would have meant that they stopped manufacturing CDs, leaving all copies made in record stores, used disc bazaars etc. Right now, said discontinuation would imply the complete annihilation of that content in an absolute way, either due to disinterest of the hegemonic figure or as part of a censorship plan or business strategy. This is deeply worrying for us as a community, as our consumption increasingly depends on streaming services, we will proportionally depend on the decisions of large entities (with their own agendas) to mediate our media consumption.

We are sold the idea that all the information is in "the cloud" a sort of infallible platonic world of ideas where all our information is safe forever, but as I read years ago somewhere: "The cloud does not exist; it is only someone else's computer", and indeed it is, the cloud is a lot of hard drives in a warehouse in a cold country that is totally fallible; proof of this how Myspace permanently deleted 50 million songs (Kreps, 2019).

Logically there are illegal ways to store streaming files, so by the time we are already $100 \%$ dependent on streaming we will have to rely on hackers to keep a worldwide wealth of information: having memory as a collective will be an illegal act. On the other hand, perhaps music is moving away from the perpetual nature of recordings and is being brought closer to its much more ephemeral performative genesis. For the author, knowing that their content can disappear at any time, might mean that they can change their way of expression, perhaps even taking risks that they would avoid if they were engaging with the medium of static recordings. Perhaps, owning things perpetually is an anachronistic necessity too, and streaming consumption is more suited to a more dynamic, ephemeral and portable conception of the self.

\section{The algorithmic songwriter}

And where is the creator in this whole panorama? Probably in the same place they have been historically: in the middle of the power groups that mediate their relationship with the public. But let's not fall into a naive reductionism: things have changed a lot from the 
days of those cotton field workers who were made to perform on record and did not receive a penny. A long road has led us far from that into a situation where solo performers are able to record themselves at home and distribute themselves digitally. Undoubtedly there is still a mediation of hegemonic groups, but in a much less restrictive way. What is certain is that the recording songwriter must now get his place in a media world marked by instagramism in a much more autonomous way.

Spotify, aswementionedearlier,replicatesthestructure of a social network: followers, number of listeners per song, and even hierarchizes artists using those numbers. The platform gives the artists access to hard data on the consumption of their music immediately, which further neuroticizes the artist-public relationship. Until a few years ago the success or failure of a musical release was relative to many variables: record sales, critical reviews, radio play, concert ticket sales, etc. Now it is related to a single variable: how many reproductions it has had. And since all the releases are on Fridays, already by Tuesday of the following week, it is understood that we have had enough time to know if the algorithm has benefited us or not. If they don't have enough plays, many artists give up promoting a release at that time; if they have been completely ignored by the algorithm by that time, there is not much they can do for the track. The singer/songwriter, as we suggested before, will adapt his creation to algorithmic needs, making happy songs, or having features that software can identify. This adaptation is natural in the history of popular music:

We might also think of Mark Katz's (2004) notion of phonographic effects -where musicians, during the advent of early recording technology, altered their style of play to be better captured by microphonesto trace whether or not there are any discernible algorithmic effects taking place in these services. As these systems become primary means of distribution, musicians may attempt to record certain styles or sounds or resort to particular information generation techniques because they are easier or more likely to be picked up by algorithms... These artists use a variety of tactics to game the algorithms, naming themselves after popular search terms (such as the name of a popular artist or song), cloning popular songs, releasing the same song under a thousand different titles and other such techniques (Morris, 2015, pp. 457-458).

Economically speaking, most artists today can't make a living from of streaming revenues:

First, musicians argue that on-demand streaming services undermine sales of digital files and physical media and, therefore, they are not a financial model that can sustain their musical careers. Underpinning this, however, is a broader aesthetic and moral argument about what music should be worth, with the micro-payments generated by each stream being seen as devaluing music itself (Marshall, 2015, p. 181).

The issue is the scale. To the extent that Spotify has more subscribers, there will be more money for everyone, but until then creators must continue to live in precarious conditions, but with the hope that eventually, one of their songs will become viral and they will make money off it. That kind of hoax is really common in capitalist oppression: the system makes the exploited workers believe that any time soon their conditions can change and they will improve their way of life.

\section{Conclusions}

There is nodoubtabout the relationshipbetween streaming and the interests of large corporations, and how the promise of modernity serves as a perfect screen to hide those interests. Logically, the music industry has always responded to capitalist interests, but before that agenda was explicit: they had to sell records. Now, streaming is presented as a kind of horizontal dynamic with a deep opacity, not only in its economic agenda, but also ideologically.

Algorithmic curatorship presents an almost perfect control mechanism for the masses: first because of its computational objectivity, and secondly because, by over-subjectivizing consumption, the collective is dismantled: before, all of Mexico could simultaneously see a discriminatory act in a TV show and pronounce themselves on the matter. Now the algorithm succeeds in atomizing the content, so that a community is not built around it, but a group of disjointed subjects, without awareness of the community or the political possibilities of it.

Of course, I don't understand this power dynamic in an old fashioned way were an hegemonic figure coerces a depowered agent; I see this situation in a way closer to Foucault's (1978, p. 92) understanding of power:

I do not mean "Power" as a group of institutions and mechanisms that ensure the subservience of the citizens of a given state. By power, I do not mean, either, a mode of subjugation which, in contrast to violence, has the form of the rule. Finally, I do not have in mind a general system of domination exerted by one group over another, a system whose effects, through successive derivations, pervade the entire social body (Foucault, 1978, p. 92)

All the agents involved in this new dynamic contribute to the perpetuation of it, and it's not bad news for everyone: several artists that know how to play the algorithmic game manage to rise above the competition. Hence, I'm not saying that this new dynamic is evil, I'm just saying that is not that new. 


\section{References}

Allen Anderson, P. (2015). Neo-muzak and the business of mood. Critical Inquiry, 41(4), 811-840. https://doi.org/10.1086/681787 Benjamin, W. (2005). The work of art in the age of mechanical reproduction. Los Angeles: UCLA School of Theater.

Benjamin, W. (2008). The work of art in the age of its technological reproductibility and other wrtings on media. London: Harvard University Press.

Cheney-Lippold, J. (2011). A new algorithmic identity soft biopolitics and the modulation of control. Theory, Culture \& Society, 28(6), 164-181. https://doi.org/10.1177/0263276411424420

Crowe, C. (2003). My number one. Retrieved from: http://www.theuncool.com/journalism/rs937-my-number-1-pet-sounds/.

DeNora, T. (2004). Music in everyday Life. London: Cambridge University Press.

Drott, E. (2018). Why the next song matters: streaming, recomendation, scarcity. Twentieth-Century Music. 15(3), 325-357. Cambridge University Press. https://doi.org/10.1017/S1478572218000245

Eriksson, M., Fleischer, R., Johansson, A., Snickars, P and Vonderau, P. (2019). Spotify Teardown: Inside the Black Box of Streaming Music. London: MIT Press.

Flichy, P. (2007). The internet imaginaire. Boston: MIT Press.

Foucault, M. (1978). The history of sexuality: an introduction. New York: Pantheon Books.

Frith, S. (1986). Why songs have words. Sociological Review Monograph Series: 34(1), 77-106. https://doi.org/10.1111/j.1467954X.1986.tb03315.x

Galindo, B. (2002). Vasos Comunicantes. Madrid: SGAE.

Galloway, A. (2004). Protocol. London: MIT Press.

Gutiérrez, V. (2019). El disco ha muerto. ¡Viva el streaming! El Economista. Retrieved from: https://www.eleconomista.com.mx/ arteseideas/El-disco-ha-muerto-viva-el-streaming-20190424-0149.html

Hennion, A. (2010). Gustos musicales: de una sociología de la mediación a una pragmática del gusto. Comunicar 17(34), 25-33. https://doi.org/10.3916/C34-2010-02-02

Hesmondhalgh, D. (2019). Comunicación personal vía correo electrónico. Fecha: 6-4-2019.

Hogan, M. (2015). How music playlists are curating the future of music. Pitchfork. Retrieved from: https://pitchfork.com/features/ article/9686-up-next-how-playlists-are-curating-the-future-of-music/

Latour, B. (2005). Reassembling the social. London: Oxford.

Kreps, D. (2019). Myspace Lost All Music Uploaded to Site Prior to 2015. Rolling Stone. Retrieved from: https://www. rollingstone.com/music/music-news/myspace-lost-music-809455/

Kowalski, R. (1979). Algorithm = Logic + Control. Comunications of the ACM, 22(7). https://doi.org/10.1145/359131.359136

Manovich, L. (2016). Designing and Living Instagram Photography: Themes, Feed, Sequences, Branding, Faces, Bodies. Retrieved from: http://manovich.net/content/04-projects/097-designing-and-living-instagram-photography/instagram_book_ part 4.pdf

Marshall, L. (2015). 'Let's keep music special. F-Spotify': on-demand streaming and the controversy over artist royalties. Creative Industries Journal, 8(2), 177-189. https://doi.org/10.1080/17510694.2015.1096618

Morris, J. (2015). Curation by code: Infomediaries and the data mining of taste. European Journal of Cultural Studies, 18(4-5) 446-463. https://doi.org/10.1177/1367549415577387

Napoli, p and Caplan, R. (2017). Why media companies insist they're not media companies, why they're wrong, and why it matters. First Monday, 22(5). https://doi.org/10.5210/fm.v22i5.7051

Resnikoff, P. (2018). Apple Is Shutting Down iTunes Music Downloads on March 31st, 2019, Sources Say. Digital Music News. Retrieved from: https://www.digitalmusicnews.com/2018/04/06/apple-shutting-itunes-music-downloads/

Platoni, K. (2006). Pandora's Box: Can a company's musicological data mining breathe new life into the music industry? East Bay Express, January 11. Retrieved from: https://www.eastbayexpress.com/oakland/pandoras-box/Content?oid=1080116

Prey, R. (2018). Nothing personal: algorithmic individuation on music streaming platforms. Media, Culture \& Society, 40(7) 1086-1100. https://doi.org/10.1177/0163443717745147

Srnicek, N. (2017). Platform capitalism. London: Polity Press. 